 \\ z Filologii Polskiej \\ i Słowiańskiej
}

\author{
Jadwiga Woźniak-Kasperek \\ (Instytut Informacji Naukowej i Studiów Bibliologicznych \\ Uniwersytetu Warszawskiego)
}

\section{Bibliografia w cyfrowej przestrzeni informacyjnej}

Jesteśmy świadkami zmiany paradygmatu bibliograficznego. Dynamicznie przekształcająca się przestrzeń informacji cyfrowej, w tym sieciowej, oddziałuje na uniwersum bibliograficzne, stając się źródłem zarówno nowych możliwości, jak i trudności, z którymi muszą się zmagać i bibliografowie, i użytkownicy bibliografii. Jednym z największych problemów jest wielkość zasobów, które mogą lub powinny być objęte rejestracją bibliograficzną. O konsekwencjach zaniechań w tym względzie wspomnę w dalszej części artykułu. Niebagatelna jest także kwestia przenoszenia dotychczasowego dorobku bibliografii do środowiska cyfrowego oraz problemy wynikające z pierwotnego tworzenia bibliografii w tym środowisku. W natłoku zmian i nowości nie można zapomnieć, że gdyby nie zapał i benedyktyńska praca zastępów bibliografów na całym świecie, dziś wiedzielibyśmy dużo mniej o tym, czym się karmiło życie, jak wyglądały nauka czy sztuka, kultura w dalekiej i nieodległej przeszłości. Trudno przecenić rolę i znaczenie bibliografii, ładu bibliograficznego i związanego z nim ładu informacyjnego, zwłaszcza w naszych czasach, w których problem stanowi nadmiar informacji, a nie jej niedostatek. W dodatku ilość ta zbyt

This is an Open Access article distributed under the terms of the Creative Commons Attribution 3.0 PL License (creativecommons.org/licenses/by/3.0/pl/), which permits redistribution, commercial and non-commercial, provided that the article is properly cited. (C) The Author(s) 2014.

Publisher: Institute of Slavic Studies, PAS \& The Slavic Foundation

[Wydawca: Instytut Slawistyki PAN \& Fundacja Slawistyczna] 
często nie idzie w parze z jakością. Bibliografie na szczęście nadal są bastionami „doskonałości” i pielęgnowania dobrych praktyk utrwalania informacji o rejestrowanych obiektach, relacjach między nimi oraz między obiektami spisu bibliograficznego a kulturą, $\mathrm{w}$ tym nauką.

Spośród wielu problemów, które lokują się w obszarze wyznaczonym tytułem artykułu, nieco głębszej analizie chciałabym poddać zagadnienia zmiany postaci bibliografii oraz nowych możliwości i narzędzi wyszukiwania w spisach bibliograficznych. Nie będę analizować problemów, sukcesów i porażek związanych z przeniesieniem (lub tworzeniem od początku) konkretnych bibliografii w przestrzeń cyfrowo-sieciową. Każdy z takich przypadków jest indywidualny, a ja chcę się skupić na zagadnieniach w ich wymiarze nieco powszechniejszym.

\section{Zadania bibliografii}

Mianem bibliografii określa się dziś zarówno dyscyplinę naukową (teorię bibliografii), jak i praktyczne działania, których rezultatem są spisy bibliograficzne lub szerzej - serwisy informacyjne o charakterze bibliograficznym - oraz rezultaty tych działań w postaci spisów bibliograficznych. Żadna z tych sfer przejawiania się bibliografii nie jest ani autonomiczna, ani odizolowana od wpływów bliższego i dalszego otoczenia. Silna wydaje się dziś potrzeba refleksji na temat istnienia spisów bibliograficznych w różnych kontekstach, przestrzeniach społecznych i informacyjno-wyszukiwawczych. Zbyt często dyskusję o społecznym, w tym naukowym, znaczeniu i funkcjonowaniu bibliografii zastępuje dyskusja o skądinąd ważnych - kwestiach takich jak na przykład standardy i kompletność opisu, formaty ${ }^{1}$, typ stosowanego języka informacyjno-wyszukiwawczego.

1 Zdecydowanie wypowiada się na ten temat między innymi Anna Sitarska, pisząc o konieczności „uświadomienia sobie, jakie są funkcje struktury danych bibliograficznych (w uproszczeniu nazywanych 'formatami bibliograficznymi') w procesach automatycznego przetwarzania. Rozpleniło się bowiem szkodliwe uproszczenie, sprowadzające funkcje tych 'formatów' do widocznej gołym okiem wyliczanki elementów opisu oraz do zasad postaci zapisu danych, tj. nazwy elementu + właściwej informacji. Tymczasem dopiero analiza efektów przetwarzania ujawnia, że pozycja (inaczej - miejsce w strukturze danych) oraz drobne składniki nazw danych (np. powtarzalne i symboliczne prefiksy nazw, tj. etykiet pól i podpól) decydują o indeksowaniu, szeregowaniu lub sposobie wyświetlania danych na monitorze, lub o kroju czcionki wydruku" (Sitarska, 2012, s. 7). 
Coraz więcej bibliografii jest digitalizowanych lub pierwotnie tworzonych w środowisku cyfrowym, mimo to dotkliwie odczuwa się brak integracji tych i innych typów zasobów elektronicznych. Jak ogarnąć to bogactwo? Co zrobić, żeby na czas wykorzystać szanse i ominąć zagrożenia? Tempora mutantur et nos mutamur in illis - a przynajmniej powinniśmy zmieniać się tak jak czasy, w których żyjemy. I jest to wezwanie nie do płytkiego, bezmyślnego nadążania za modą, dyktatem czasów, ale do głęboko przemyślanego przynoszącego korzyść dostosowania się do potrzeb, wymagań oraz możliwości czasu i środowiska, w którym budujemy nasz fragment historii.

Wielowiekowe istnienie bibliografii i jej przemiany nie zmieniły istotnie jej najogólniejszych zadań. Zadania te są dwojakiej natury. Z jednej strony bibliografie służą celom utylitarnym, umożliwiają lub co najmniej ułatwiają osobom zainteresowanym dotarcie do właściwych publikacji (lub - jak dziś częściej je nazywamy - obiektów informacyjnych), pośredniczą między informacją o obiekcie a potencjalnym odbiorcą, użytkownikiem, umożliwiają identyfikację, rozpoznanie obiektu i zaspokojenie doraźnych potrzeb informacyjnych. Bibliografie mają też inne, nie mniej ważne, zadanie. Są skarbnicami pamięci, obrazem stanu szeroko rozumianej kultury w określonym czasie i miejscu, dokumentem, który ma znamiona dokumentu archiwalnego przeznaczonego do zachowania dla przyszłych pokoleń. Dziś zbyt często traci się z pola widzenia to zadanie historyczno-archiwizacyjne, a sprowadza się bibliografię do (bardzo ważnej, ale nie jedynej czy najważniejszej) roli narzędzia informacyjno-wyszukiwawczego. Różne typy spisów bibliograficznych w różnym stopniu są powołane do pełnienia tych dwu funkcji. Inaczej to wygląda w przypadku bibliografii narodowej, a inaczej np. w przypadku bieżących bibliografii specjalnych, choć i w ich grupie nie ma jednorodności. Bibliografie takie jak Bibliografia językoznawstwa slawistycznego ${ }^{2}$ ze względu na swój wyjątkowy charakter, którego jednym z wyrazów jest międzynarodowy zasięg wydawniczy tej bibliografii, należą do spisów, w wypadku których oba zadania mają równą, wysoką rangę.

Porażką bibliografii jest niezarejestrowanie w spisie tych obiektów, które powinny w nim się znaleźć.

„Bibliografia poprzez nieobecność rejestracji [dokumentów, które powinny być zarejestrowane - J.W.K.] wskazuje te pola zagadnieniowe, które są mało lub w ogóle

2 Bibliografia językoznawstwa slawistycznego w latach 1995-2003 wydawana była w tradycyjnej postaci drukowanej; jej kontynuatorką jest dostępna online bibliograficzna baza danych światowego językoznawstwa slawistycznego iSybislaw (www.isybislaw.ispan.waw.pl). 
nieinfiltrowane przez aktywność naukową, choć ma to inny wymiar i skutek dla funkcjonowania nauk humanistycznych, a inny w przypadku dziedzin przyrodniczo- matematycznych. Zaniechanie informacyjne przez nieuwzględnienie pozycji bibliograficznej lub przez jej niewłaściwe zlokalizowanie w informatorze może prowadzić do skutków wprost katastrofalnych w życiu społeczności, co jednocześnie dowodzi słuszności tezy o tym, że bibliografia jest w jakimś stopniu refleksem otaczającej nas rzeczywistości [...]. A jej niedoskonałość może na tę rzeczywistość w sposób znaczący wpływać. Życie dostarcza wielu przykładów na poparcie tej tezy" (Nowak, 2009, s. 160).

Jako ilustrację tej tezy Nowak przytacza przypadek, gdy niezarejestrowanie w bibliografii pewnej pracy dyplomowej sprawiło, że odkrycie penicyliny „opóźniło” się o ponad 30 lat. „Zdumiewające jest, jak często pozornie niezależnie funkcjonujące od siebie zdarzenia w przestrzeni społecznej, w pewnych warunkach zbliżają się do siebie, nawet przecinają, doprowadzając do wielu ważnych następstw" (Nowak 2009, s. 161).

\section{Bibliografia a katalog biblioteczny}

Intensyfikacja wykorzystywania komputerów i technologii informacyjnych w pracach bibliograficznych spowodowała zasadnicze zmiany w organizacji opracowywania bibliografii i w sposobach realizacji funkcji wyszukiwawczej. Opis katalogowy i opis bibliograficzny, dawniej będące dwoma różnymi typami opisu, dziś są sporządzane według tych samych przepisów i często w tym samym formacie danych. Jeden i ten sam rekord bibliograficzny może „obsługiwać” zarówno katalog, jak i bibliografię. Stąd zapewne biorą się pozbawione racji opinie o braku istotnych różnic między katalogiem i bibliografią. Z mocą należy przypomnieć, że ani bibliografia nie jest katalogiem, ani katalog bibliografią. Zawartość katalogu bibliotecznego wyznacza historia i aktualny stan kolekcji bibliotecznej jednej lub większej liczby bibliotek (w wypadku katalogów centralnych), w tym zmienna polityka gromadzenia zbiorów zależna od czynników finansowych, organizacyjnych, a nierzadko politycznych czy personalnych. W skład kolekcji bibliotecznych mogą wchodzić zasoby całkowicie przypadkowe lub determinowane np. doraźną polityką instytucji macierzystej. Brakować może z kolei tego, co wydawałoby się, że bezwzględnie powinno być $\mathrm{w}$ danej bibliotece. W katalogach bibliotecznych można również znaleźć rekordy bibliograficzne zasobów, których biblioteka realnie nie posiada, 
a jedynie ma do nich czasowy dostęp na mocy wykupionych licencji. Katalog inwentaryzuje zatem rzeczywisty i aktualny - swoiście niekiedy rozumiany stan „posiadania” instytucji, zawartość katalogu ulega zmianie, gdy zmienia się zasób. Tymczasem bibliografia to świadomie i celowo dobrany, uporządkowany, w przyjętych granicach bliski kompletności zasób obiektów bibliograficznych (metadanych o obiektach informacyjnych) bez względu na miejsce ich przechowywania czy stan zachowania. Jest specyficznym obrazem stanu produkcji wydawniczej, piśmienniczej, ludzkiej kreatywności w określonym miejscu, czasie i warunkach. Wyłączenie - np. w rezultacie zagubienia - obiektu z kolekcji bibliotecznej skutkuje usunięciem odpowiedniego rekordu z katalogu, podczas gdy bibliografia jest „niewrażliwa” na tego typu sytuacje. Problem nieuzasadnionego utożsamiania katalogu z bibliografią nabiera szczególnego znaczenia $\mathrm{w}$ wypadku bibliografii narodowych. Nie ma równości pomiędzy bibliografią narodową a katalogiem na przykład biblioteki narodowej, choć to zbiory współzależne, a w skrajnym przypadku nawet pokrywające się. Inne są też wymagania i oczekiwania co do jakości i wartości danych. O ile w katalogu dopuszcza się pewne uproszczenia czy rezygnację z wyższych poziomów szczegółowości opisu bibliograficznego, o tyle w bibliografiach na ogół nie ma na to miejsca. Kończąc ten wątek, chciałabym jeszcze dodać, że chociaż jestem zdecydowaną przeciwniczką unifikowania bibliografii i katalogów bibliotecznych, to opowiadam się za stwarzaniem możliwości przeszukiwania zarówno katalogów, jak i bibliografii, z jednego miejsca, wspólnego „okna” wyszukiwawczego, o ile dla szukającego nie ma znaczenia, czy w odpowiedzi otrzyma informacje o zbiorze „idealnym”, czy realnym.

\section{Postać bibliografii}

Współcześnie spisy bibliograficzne występują w trzech komplementarnych postaciach: drukowanej, cyfrowej (na nośnikach fizycznych i jako dokumenty sieciowe) oraz w zanikającej postaci mikroform. Niektóre bibliografie przestały się ukazywać w postaci drukowanej. Mimo że generalne przesłanie mojego artykułu jest protechnologiczne, to jednoznacznie chcę się opowiedzieć za wyłącznie głęboko przemyślaną rezygnacją z drukowania spisów bibliograficznych. W pewnych sytuacjach jedynym wiarygodnym źródłem do badań może być tylko bibliografia drukowana. Bibliografia $w$ postaci bazy danych $z$ uwagi na swoją płynność, wyrażającą się w dyskretnym zastępowaniu jednych danych innymi, 
może nie odzwierciedlać rzeczywistego kształtu opisów bibliograficznych czy charakterystyk treściowych sporządzonych w określonym czasie. Okoliczność ta jest szczególnie ważna dla teoretyków bibliografii, którzy badają same spisy bibliograficzne. Czasami najważniejsze jest nie to, żeby otrzymane dane były aktualne, ale żeby były zgodne ze stanem w określonym momencie. W wypadku części bibliografii w postaci baz danych w ogóle nie jest możliwe prowadzenie pewnych badań porównawczych, które były realizowane na materiale bibliografii drukowanych. Dlatego rozwiązaniem optymalnym jest utrzymywanie dwu wersji spisu - drukowanej (lub w postaci pliku PDF) i cyfrowej ${ }^{3}$. W tym względzie chlubnym przykładem jest Bibliografia historii polskiej, której sukcesywnie wydawanym rocznikom drukowanym towarzyszy baza danych. W 2010 r. Biblioteka Narodowa zaprzestała drukowania Przewodnika Bibliograficznego, ale oprócz bazy Przewodnika udostępniono cotygodniową edycję w formacie PDF, która powiela układ i grafikę drukowanych Przewodników. Przy okazji tej zmiany zaproponowano nowość - roczne kumulacje.

„Zaoferowano zatem niebagatelną «wartość dodaną» w postaci swoistego Rocznika Bibliograficznego, którym nie dysponowali użytkownicy dawnych edycji bieżącej bibliografii narodowej. [...] dodajmy, nie tylko dla analityka ruchu wydawniczego takie skumulowane spisy [...] to znakomite, trudne do przecenienia źródło informacji, znacznie ułatwiające wszelkie studia i rozbiory" (Franke, 2013b, s. 11).

Jak widać na tym przykładzie, głęboko przemyślana zmiana, choćby na pierwszy rzut oka wydawała się niekorzystna, wcale taką nie musi być.

Bez wątpliwości bibliografie, żeby nie przegrać wyścigu z czasem, którego jednym $\mathrm{z}$ wyznaczników jest wzrost znaczenia i potencjału WWW, muszą istnieć w sieci. I nie chodzi tu o to, żeby udostępniać jakieś dane, ale żeby robić to tak, aby nie zmniejszać potencjału intelektualnego i zasięgu oddziaływania bibliografii. Bibliografia jest dziełem spójnym, zintegrowanym, „okazem pracy naukowej".

3 „Eksplozja cyfrowych mediów systematycznie eliminuje drukowane wersje bibliograficznych edycji. Niektóre z nich kończą żywot, inne migrują do sieciowych zasobów. Wcielają się tam w odmienne formy, przede wszystkim bazy danych, lecz także cyfrowe ekwiwalenty wersji drukowanych, wreszcie przybierają postać egzotycznych na bibliograficznym polu rozwiązań, jakim są blogi. Przemiana BABINU [Bibliografii Analitycznej Bibliotekoznawstwa i Informacji Naukowej - J.W.K.] w jeden z blogów (BABIN 2.0), prowadzonych na stronie Biblioteki Narodowej służyć może za przykład mocno dyskusyjnych zabiegów «modernizacyjnych», a w istocie poważnie redukujących bibliograficzny projekt” (Franke, 2013b, s. 9). 
Jej wartość

„leży nie w udostępnianiu pojedynczych rekordów, ale przede wszystkim w ujawnieniu relacji, łączących elementy zawartości, a w tym treści i formy lub chronologii wydania oraz powstania grup obiektów opisywanych w rekordach [...], odpowiednio powiązanych metodami układu, indeksowania oraz doboru różnego rodzaju odsyłaczy" (Sitarska, 2012, s. 22).

Warto wreszcie wspomnieć o - moim zdaniem nagannej - nierzadkiej praktyce rezygnowania $\mathrm{z}$ układów treściowych $\mathrm{w}$ wypadku przejścia bibliografii do postaci bazy danych. Dotychczas nie ma zastępników dla dobrze skonstruowanego i odpowiednio głębokiego układu systematycznego, działowego lub klasowego. Jeśli wyszukiwanie ma być jak najbardziej kompletne i najmniej czasochłonne, nic nie zastąpi odpowiedniego układu zrębu głównego bibliografii.

Wreszcie kwestia moim zdaniem istotna, choć chyba nieciesząca się szerszym zrozumieniem i poparciem. Znany powszechnie podział bibliografii na retrospektywne, bieżące i prospektywne zdaje się sugerować, że mamy do czynienia z trzema autonomicznymi gatunkami bibliograficznymi. W wielu wypadkach takie podejście nie skutkuje żadnymi lub większymi konsekwencjami praktycznymi, ale w pewnych tak. Ma to miejsce na przykład w przypadku bibliografii narodowej. Bibliografia narodowa retrospektywna, bieżąca i ewentualnie prospektywna powinny być systemem naczyń połączonych, zapewniać spójność i ciągłość w czasie i w przestrzeni informacyjno-organizacyjnej. Istota pewnych problemów szczegółowej metodyki bibliograficznej pozostaje bowiem niezmienna i niezależna od zasięgu czasowego bibliografii. Poza tym w warunkach wykorzystywania technologii informacyjnych brak koordynacji działań i spójności danych skutkuje dublowaniem prac i marnowaniem szansy na powstanie informacyjnej wartości naddanej.

Pełne wykorzystanie możliwości technologii cyfrowych przy sporządzaniu bibliografii nie jest zamachem na ich naukowość, rangę, miejsce w systemie komunikacji naukowo-społecznej itd., ale szansą i nadzieją na poprawienie między innymi tak ważnego parametru, jak użyteczność informacyjna spisu, co w przyszłości może ocalić pewne bibliografie przed zaprzestaniem ich opracowywania. Adresaci bibliografii coraz częściej oczekują również, że kierowana do nich odpowiedź nie będzie ograniczona li tylko do metadanych, a wręcz przeciwnie - będzie zawierać także pełne teksty dokumentów lub przynajmniej odesłania (tzw. linki) do tych pełnych tekstów. To rodzi z kolei problemy natury zarówno technicznej, jak i intelektualno-prawnej. Nie można jednak zniechęcać się trudnościami, bo przyszłość wszelkich serwisów informacyjno-wyszukiwawczych zdaje się coraz mocniej związana z pełnotekstowością, przy czym tekst 
jest tu rozumiany szeroko, bez ograniczenia do tekstu piśmienniczego. Coraz więcej zasobów bibliograficznych ma dziś mniej lub bardziej rozbudowaną strukturę hipertekstową, gdzie jednym z powiązań jest intertekstualna relacja łącząca metadane bibliograficzne $\mathrm{z}$ tekstami charakteryzowanymi przez te metadane. Zbyt rzadko uświadamiamy sobie, że metadane bibliograficzne są podstawą identyfikacji, weryfikacji i wiarygodności tekstu. Jak odnosimy się do tekstu, któremu nie towarzyszy na przykład taka „prosta” metadana jak nazwa autora? Czy tak samo jak do tekstu z oznaczonym autorstwem? Pełnotekstowość jest również warunkiem połączenia indeksowania wykonywanego przez profesjonalistów $\mathrm{z}$ indeksowaniem automatycznym lub wspomaganym komputerowo ${ }^{4}$. Kolejnym krokiem w budowaniu tej struktury mogłoby być łączenie zasobów bibliograficzno-tekstowych $\mathrm{z}$ informacjami o charakterze faktograficznymi (funkcjonalnymi, sytuacyjnymi, zdarzeniowymi itp.), czyli rozwijanie struktury w kierunku map wiedzy. Przejście bibliografii od statycznej listy, umożliwiającej ,jedynie” wyszukiwanie opisów dokumentów, do postaci zasobu, po który można sięgnąć, kierując się odpowiednimi połączeniami, to ważny krok na drodze ku pełnemu zaistnieniu bibliografii w sieci. Zintegrowanie bibliografii $z$ innymi elementami pejzażu sieci, z jej zasobami informacji i metainformacji - piśmienniczej i multimedialnej - wydaje się dziś pilnym i ambitnym zadaniem czekającym na realizację.

W problematykę istnienia bibliografii w sieciowej przestrzeni informacyjnej wpisuje się również tzw. Internet lub Web społecznościowy (2.0). Standard Web 2.0 zakłada poza dostępem do edycji danych z poziomu przeglądarki internetowej (mechanizm wiki) łączenie w jednym serwisie wielu narzędzi Web 2.0 - komentarzy, recenzji, możliwości tworzenia indywidualnego profilu z przypisanymi kolekcjami, określony interfejs i funkcjonalność serwisu. Serwisy Web 2.0 cechuje łatwość użytkowania, wynikająca z przejrzystej kompozycji stron, dużej szybkości ich wczytywania i powtarzających się funkcji. Nie sposób wyobrazić sobie otwarcia baz bibliograficznych na dowolne działania użytkowników bez moderacji zmian przez nich wprowadzanych. Ale umożliwienie użytkownikom wyrażania opinii, podpowiadania słów kluczowych czy „prenumerowania” pewnych treści bibliografii jest możliwie i pożądane. Zapewne część bibliografów uzna, że to dopuszczanie pogan do czynności zarezerwowanych dla kapłanów wiedzy, ale doświadczenia licznych bibliotek

\footnotetext{
${ }^{4}$ Por. rozważania zawarte na przykład w książce Piotra Malaka (Malak, 2012).
} 
potwierdzają zasadność takiego otwarcia się na użytkowników. Indeksacyjna aktywność użytkowników niewątpliwie przyczynia się do likwidowania wielu barier informacyjnych, np. terminologicznej. Dlatego biblioteki na całym świecie z większym lub mniejszym entuzjazmem próbują włączać użytkowników w opracowanie zbiorów, czyniąc to np. poprzez zachęcanie do tagowania proponowania charakterystyk dokumentów. Robi tak np. Staatsbibliothek w Berlinie, wiele bibliotek - zwłaszcza publicznych - w USA, serwisy typu Amazon.com czy Empik.com.

„Nie można nie dostrzec, że aplikacje web 2.0 to przecież wysiłki na polu typowo bibliotekarskim: zbierania, magazynowania, opracowania i udostępniania informacji. W efekcie [...] w stosunkowo szybkim tempie pojawiły się koncepty adaptowania rozwiązań ideologicznych i technologicznych sieci drugiej generacji do praktyki bibliotekarstwa" (Zając, 2007, ss. 96-97).

Bibliografia językoznawstwa slawistycznego jako bibliografia naukowa kierowana do wykształconego i świadomego odbiorcy próbuje podjąć takie wyzwanie ${ }^{5}$.

\section{Narzędzia wyszukiwawcze}

Dobrze skonstruowany układ bibliografii, odsyłacze czy indeksy to „serce” systemu wyszukiwania informacji w bibliografii. Zrobienie ich to sztuka, do uprawiania której niezbędne są wiedza i doświadczenie. Mówiąc o układzie bibliografii, najczęściej ma się na myśli cztery następujące elementy: 1) kompozycję całości bibliografii, 2) układ zasadniczy zrębu głównego, 3) układ wewnętrzny w obrębie poszczególnych grup (często na określenie tego gatunku układu używa się terminu szeregowanie), 4) indeksy jako uzupełnienie układu zrębu głównego.

Tradycyjnie układy zrębu głównego dzieli się na formalne i treściowe (rzeczowe). Układy formalne to m.in. układ według form wydawniczych, piśmienniczych, autorów, tytułów, miejsc wydania, nazw drukarń, języka, chronologii (wydawniczej, piśmienniczej, biograficznej autorów), schematów organizacyjnych instytucji. Dziwi stosowanie niekiedy w bibliografiach dziedzin lub zagadnień układu alfabetycznego. Użytkownik zamiast skupień treściowych, którymi na ogół się interesuje, otrzymuje abecadłowy porządek haseł

${ }^{5}$ Por. informację na ten temat w tekście Zofii Rudnik-Karwatowej zamieszczonym w tym tomie. 
autorskich. Jeśli bibliografia rejestruje niewielką liczbę dokumentów, to układ taki nie jest nadmiernie uciążliwy. Jednak w zestawieniach obszerniejszych jest on niefunkcjonalny i nie powinien mieć zastosowania. W kategorii układów według kryteriów treściowych najczęściej wyróżnia się układy według tzw. kolejności logicznej rejestrowanego materiału bibliograficznego (układ działowy i systematyczny), układ przedmiotowy, klasowy oraz według chronologii przedmiotowej. Na styku układów formalnych i treściowych lokuje się układ krzyżowy, będący najczęściej połączeniem dwu typów układów, najczęściej alfabetycznego z przedmiotowym. Układ zrębu głównego bibliografii decyduje o tym, które cechy zostaną wysunięte na pierwszy plan, staną się prymarnymi kluczami wyszukiwawczymi, powinien zatem być wyrazem świadomej intencji bibliografa zwrócenia uwagi na te cechy, które z punktu widzenia potrzeb i oczekiwań użytkowników bibliografii są najważniejsze. Przejście bibliografii do środowiska cyfrowego nie zwalnia jej twórców z obowiązku troski o zastosowany układ materiału. Część korzystających ze spisów wykorzystuje przecież funkcję przeglądania klas wyodrębnionych w układzie, nie wszyscy skupiają się tylko i wyłącznie na trafianiu w punkt wyszukiwawczy (ang. searching).

Wbrew pozorom sporo problemów przysparza użytkownikom szeregowanie pozycji w obrębie grup wyznaczanych przez układ. Sposób szeregowania powinien być nie tylko poprawny, tj. zgodny z obowiązującymi normami i wiedzą, lecz także użyteczny. W systemach, gdzie szeregowanie realizowane jest przez oprogramowanie, dochodzi jeszcze jeden aspekt - wartości porządkowej znaków w tablicach szeregowania różnych systemów. Niekiedy problemy $\mathrm{z}$ odnalezieniem informacji biorą się $\mathrm{z}$ tego, że pewne programy stosują $\mathrm{tzw}$. szeregowanie wyrazowe, a inne - szeregowanie znakowe, przy zastosowaniu różnej wartości porządkowej znaków. Do tego dodać jeszcze należy, że w niektórych systemach wyświetlane znaki diakrytyczne są pomijane w szeregowaniu, a znaki z diakrytykami traktowane jak znaki bez diakrytyków. Wydawałoby się, że szeregowanie nie ma większego wpływu na skuteczność wyszukiwania. Praktyka uczy, że jest inaczej (Woźniak-Kasperek, 2010). W takich bibliografiach jak Bibliografia językoznawstwa slawistycznego, rejestrujących obiekty wielojęzyczne wielu alfabetów, zagadnienia szeregowania nabierają wyjątkowo dużego znaczenia i są nie lada wyzwaniem dla autorów bibliografii.

Istotnym elementem systemu informacyjno-wyszukiwawczego bibliografii są indeksy. Nawet najlepszy układ nie zaspokoi wszystkich potrzeb. Dokonując skupienia opisów według pewnych cech, rozprasza opisy, które mają inne cechy wspólne, a których skupienie może być także pożyteczne. Celem indeksów jest 
tworzenie skupień według tych innych cech, czyli ukazanie zawartości bibliografii z punktu widzenia odrębnego od przyjętego w zrębie głównym. Indeksy

„stanowią dopełnienie układu zasadniczego bibliografii poprzez podanie klucza do jej zawartości w układzie odmiennym od układu zrębu głównego. Brak odpowiednich indeksów osłabia wartość informacyjną bibliografii. Indeksy mogą korygować dane z opisów głównych, uzupełniać je, a nawet dodawać nowe elementy, których brak w zrębie głównym" (Woźniak-Kasperek, 2010, s. 121).

Nie trzeba dodawać, że aby opracować dobry indeks, trzeba być nie tylko wytrawnym bibliografem, lecz także znawcą dziedziny, z zakresu której informacje są porządkowane w indeksie. Sam wybór typu indeksu jest zadaniem niebanalnym i niełatwym. Inny ważny czynnik to stwierdzenie, czy spis ma charakter jednorazowego przedsięwzięcia bibliograficznego, czy też mamy do czynienia z bibliografią ukazującą się periodycznie, w przypadku której prędzej czy później bibliograf powinien stanąć przed zadaniem skomasowania lub skumulowania zapisów indeksowych. Skomasowanie indeksów sprawia, że wszelkie wcześniej dokonane zmiany powodują wewnętrzną niespójność i mogą być źródłem problemów wyszukiwawczych dla użytkownika. Na pewno indeksy nie powinny powstawać poprzez mechaniczne scalanie elementów. Z kolei kumulowanie indeksów jest pracochłonne, wymaga stosunkowo dużego doświadczenia i dobrej znajomości spisu. Obecnie technika stwarza możliwość scalania zarówno indeksów, jak i zawartości zrębów głównych, co jednak nie uwalnia bibliografa od problemów analogicznych do tych, które powstają przy scalaniu indeksów.

Dopełnieniem możliwości wyszukiwawczych układu czy indeksów w przypadku, gdy bibliografia ma postać bazy danych, jest wyszukiwanie pełnotekstowe. Niekiedy irytujące ze względu na towarzyszący mu szum informacyjny, niesie ze sobą potencjał nowych możliwości objęcia wyszukiwaniem tych elementów spisu bibliograficznego, które tradycyjnie nie były nim objęte. Mam tu na myśli między innymi adnotacje i streszczenia. Do tej pory adnotacje zwykle służyły użytkownikom do dokonania na wyszukanych informacjach dodatkowej selekcji pod kątem relewancji, czyli zgodności z potrzebami szukającego. Rzadko były obiektami przeszukiwanymi przez system w „standardowej” procedurze wyszukiwania. $\mathrm{W}$ bibliografiach drukowanych i katalogach kartkowych wręcz nie było to możliwe ze względu na specyfikę dostępu do informacji w zbiorze. Moim zdaniem dziś praktykę tę można i koniecznie należałoby zmienić. Adnotacje są niezwykle bogatym źródłem najróżnorodniejszych i niekiedy wręcz bezcennych informacji (Woźniak-Kasperek, 2008). 


\section{Zakończenie}

Wskazane w artykule problemy, z jakimi zmagają się bibliografowie, w najmniejszym stopniu nie mają znamion pogłębionej analizy. Są raczej rejestrem zagadnień do pilnego przemyślenia i ewentualnego wdrożenia.

„Bibliografia przechodzi [...] okres próby związanej z rewolucją informacyjną, cyfrowo-sieciową. Zawsze zresztą rozwijała się zgodnie z rytmem wyznaczanym przez stosowane technologie. [...] Ostatnie dziesięciolecia mogą się okazać przełomowe [...]. Zmiany bowiem postępują coraz szybciej. Tym bardziej należy je rejestrować, opisywać, analizować i klasyfikować. [...] Przyszłość bibliografii może oznaczać kompleksowe przeniesienie jej do środowiska sieciowego oraz pełną integrację $\mathrm{z}$ innymi systemami informacyjno-wyszukiwawczymi przy zachowaniu tego, co w bibliografii było najważniejsze, najlepsze i do dziś skuteczne" (Pacek, 2010, s. 218).

\section{Bibliografia}

Franke, J. (2013a). Jednolite standardy bibliograficzne - anachronizm czy konieczność? W J. Franke (Red.), Bibliografia: źródła, standardy, zasoby: praca zbiorowa (ss. 271-310). Warszawa: Wydawnictwo Stowarzyszenia Bibliotekarzy Polskich.

Franke, J. (2013b). Słowo wstępne. W J. Franke (Red.), Bibliografia: źródła, standardy, zasoby: praca zbiorowa (ss. 9-12). Warszawa: Wydawnictwo Stowarzyszenia Bibliotekarzy Polskich.

Klenczon, W. (2013). Jednostka opisu bibliograficznego a jakość bibliografii narodowej. W J. Franke (Red.), Bibliografia: źródła, standardy, zasoby: praca zbiorowa (ss. 93-109). Warszawa: Wydawnictwo Stowarzyszenia Bibliotekarzy Polskich.

Krzysztofek, K. (2006). Społeczeństwo w dobie internetu: refleksyjne czy algorytmiczne? W Ł. Jonak, P. Mazurek, M. Olcoń, A. Przybylska, A. Tarkowski, \& J. M. Zając (Red.), Re: internet - spoteczne aspekty medium: polskie konteksty i interpretacje (ss. 19-41). Warszawa: Wydawnictwa Akademickie i Profesjonalne.

Malak, P. (2012). Indeksowanie treści: porównanie skuteczności metod tradycyjnych i automatycznych. Warszawa: Wydawnictwo Stowarzyszenia Bibliotekarzy Polskich.

Nowak, A. (2009). Fenomen „Bibliografii historii polskiej 1815-1914”: analiza teoretyczna. W J.Woźniak-Kasperek, \& M. Ochmański (Red.), Bibliografia: teoria, praktyka, dydaktyka: praca zbiorowa (ss. 159-166). Warszawa: Wydawnictwo Stowarzyszenia Bibliotekarzy Polskich.

Pacek, J. (2010). Bibliografia w zmieniającym się środowisku informacyjnym. Warszawa: Wydawnictwo Stowarzyszenia Bibliotekarzy Polskich.

Sadowska, J. (2004). Bibliografia w Polsce na tle tendencji międzynarodowych. W Piąta Ogólnokrajowa Narada Bibliografów. Warszawa 11-13 czerwca 2003: materialy i dyskusja (ss. 27-49). Warszawa: Biblioteka Narodowa. 
Sadowska, J. (2009). Główne problemy współczesnej polskiej bibliografii. W J. Woźniak-Kasperek, \& M. Ochmański (Red.), Bibliografia: teoria, praktyka, dydaktyka: praca zbiorowa (ss. 34-46). Warszawa: Wydawnictwo Stowarzyszenia Bibliotekarzy Polskich.

Sitarska, A. (2012). Bibliografia osobowa: korzystne i niekorzystne uwarunkowania zastosowań ICT: na przykładzie bibliografii Jana Pawła II. Białystok; Wilno: Książnica Podlaska im. Łukasza Górnickiego.

Sosińska-Kalata, B. (2005). Systemy organizacji wiedzy w środowisku sieciowym. W B. Sosińska-Kalata, \& M. Przastek-Samokowa (Red.), Od informacji naukowej do technologii społeczeństwa informacyjnego (ss. 141-162). Warszawa: Wydawnictwo Stowarzyszenia Bibliotekarzy Polskich.

Woźniak-Kasperek, J. (2006). Organizacja informacji w internetowych serwisach kontrolowanej jakości. EBIB. Pobrano 18 stycznia 2014, z http://www.ebib.info/publikacje/matkonf/ kaba/wozniak-kasperek.php

Woźniak-Kasperek, J. (2008). Narzędzia wyszukiwania treściowego w spisach bibliograficznych. W J. Woźniak-Kasperek, \& M. Ochmański (Red.), Bibliografia: teoria, praktyka, dydaktyka: praca zbiorowa (ss. 223-232). Warszawa: Wydawnictwo Stowarzyszenia Bibliotekarzy Polskich.

Woźniak-Kasperek, J. (2010). Organizacja informacji w bibliografii: tradycja i nowe możliwości. W Szósta Ogólnokrajowa Narada Bibliografów. Warszawa, 23-24 października 2008 (ss. 115-130). Warszawa: Biblioteka Narodowa.

Woźniak-Kasperek, J. (2011). Wiedza i język informacyjny w paradygmacie sieciowym. Warszawa: Wydawnictwo Stowarzyszenia Bibliotekarzy Polskich.

Zając, M. (2007). Biblioteka dziecięca 2.0 - najnowsze tendencje komunikacyjne i organizacyjne W M. Zając, \& E. B. Zybert (Red.), Biblioteki w systemie kultury jednoczącej się Europy (ss. 92-109). Warszawa: Wydawnictwo Stowarzyszenia Bibliotekarzy Polskich.

\section{Bibliography in a digital information environment}

\section{Summary}

The dynamically changing area of the digital, including web, information interacts with the bibliographic universe, bringing new opportunities as well as new problems for both the bibliographers and the users. The article analyzes the following issues: 1) The aim of bibliography. Bibliographies serve utilitarian purposes, they allow, or at the very least facilitate, the access to relevant publications; they connect the information with its potential recipient. But biblio- 
graphies fulfil more tasks. They are treasuries of memory, images of a widely understood culture in a certain time and place; documents of archival value meant to be preserved for future generations. 2) Bibliography and library catalogue. The dangers of identifying bibliography as library catalogue. 3) The form of bibliography. The advantages and disadvantages of the paper (printed) and the digital forms. Full-text resource as the target standard of bibliographic services and an opportunity of computer-aided indexing. The possibilities and advantages of using Web 2.0 tools in bibliographies. 4) Searching tools. Arrangements and indexes.

Keywords: bibliography; form of bibliography; digital environment; network; retrieval; searching

Słowa kluczowe: bibliografia; postać bibliografii; przestrzeń informacyjna; sieć; wyszukiwanie 